\title{
OFFSHORING AND FINANCIAL MARKETS
}

The paper analyses the nature and extent of the offshore world, a grey area that is playing a major role in present-day economy. The main institutions moulding this peculiar environment are discussed: preferential tax regimes, tax havens and offshore financial centers. Their role in the globalised world is outlined after a scrutiny of the specialized literature, reports by non-governmental bodies and companies' advertisings. Finally, we present a tentative reconstruction of its geographical organization, inclusive of cartographic representations of the main international networks.

Keywords: financialization, financial centres, financial space, offshore, tax haven, post industrial economy, British empire.

\section{Introduction}

During the 20th century all economic structures had to face the impact of two epochal phenomena, the communication's revolution and the financialization of the economy. As a consequence of the never-ending technological progress, the former has repeatedly reduced the friction of distance, provoking a radical change in the map of locational advantages. The result has been a new model of international distribution of production that projected its effects to the core of business management, triggering a disintegration of production cycles in contrast with the integrative pattern typical of the first industrial revolution.

The latter phenomenon, strictly linked to the first one, apparently regards only the tertiary sector, but in reality it is becoming the driving force that influences, directly or in indirectly, a growing share of corporates. It follows that the reassuring models of spatial economy theorized dur-

\footnotetext{
${ }^{1}$ (C) Battisti G. Text. 2014.
}

ing the 19th and 20th centuries (Thünen, Weber, Christaller), despite their updating (Berry, Hoover, Alonso etc.) are no longer suitable to understand the present-day economic landscape.

At the same time, it appears of primary importance to define a model of financial space, shaped by the intertwining of capital movements, as a sort of virtual reality largely superordinated to the real economic world, the latter receiving from the former the impulses that command the geographical distribution of productions. Obviously in the frame of a globalised economy the geographical range to be considered is the whole of our planet.

Following the postulates at the basis of the isotropic space, where we must arrange both homogeneous and heterogeneous phenomena, various approaches are available. In fact, we may begin studying: a) the areas considered homogeneous according to some parameters concerning the capital market; b) the "strong points" (representing concentrations of financial capital); c) the "discontinuity faults"; d) the capital flows. In the 
present work, that is part of a wider effort to formalize the subject, we will focus on a peculiar type of discontinuity, produced by the enforcement of preferential tax regimes, including the so-called "tax havens."

In the economics domain, tax havens are the tantamount to black holes in astrophysics. This latter swallow matter and eject energy and water. What the two concepts have in common is a deep transformation of the input and the capacity to modify the surrounding environment, changing its architecture and the way it works.

With the emergence of the financial crisis in 2007-2008, the subject of tax havens and the related institutions has been attracting growing attention from the governments of the leading Western economies. It stimulates the economic geographer to fill the academic gap and make the subject more readable.

\section{The nature of the offshore world}

$\mathrm{n}$ the present international system, anybody can promote a company abroad and operate through it not only in another state but worldwide. To this purpose, any jurisdiction located outside the state of residence is considered offshore as regards the jurisdiction internationally recognized where the actor takes up his official residence. This means that the whole world is offshore to any state, offshore becoming a synonym of the foreign jurisdiction.

In the past, only the economic elite could afford to operate abroad, thanks to the consensus of the political authority. Such activity used to be the bulwark of banking and finance companies that specialized in the transfer of capitals. Nowadays, owing to the generalized growth of wealth this capacity has been spreading to an ever-enlarging social group. As the advertising of a company specialized in enabling these activities reads: "With a moderate cost and new rules common businessmen and professionals can avail themselves of offshore strategies to protect their business, their properties and exploit their advantages" [1].

Why do they do it? The company's website is explicit: to benefit from

- low tax and fees requirements with reduced and controlled charges;

- protection of savings and real estates;

- minimal formalities for the company's management and bookkeeping;

- strict protection of the bank secrecy;

- favourable rules for the setting up of financial services;

- possibility to issue anonymous bearer shares.
The list, though concise, undoubtedly reveals that in the essence the aims mentioned to the potential clients are tax avoidance and evasion towards all states.

To the man in the street, this is possible thanks to the so-called tax havens, but the phenomenon is actually widely diffused. In the globalised world all countries are competing, each of them to manage the factor of production par excellence: capital. To this purpose they equip themselves to become attractive towards all foreign residents who are looking for new ways to increase their wealth. As a consequence, this praxis is involving, to varying degrees, almost all countries.

"As terms, the words offshore business and offshore company have no precise legal, tax or general business meaning, as the word offshore often means nothing more than anywhere other than the place of physical location of the person using it (i.e. overseas). Many companies are incorporated in the many onshore countries, which have tax regimes that are by statute tax advantageous for specific international purposes (...). The word offshore is more complex than the black-andwhite tax world inhabited by the media. Offshore business consists not only of tax havens but also of onshore high tax countries fiercely competing to attract international companies and individuals with all manner of tax planning, regulations and opportunities. So today the offshore world includes structures domiciled in high tax onshore countries as different as the U.K., Portugal Austria, Switzerland and the Netherlands." [2].

A glance at the conditions offered by Great Britain is enlightening. Here the final burden is generally lower than elsewhere and many taxes and fees simply do not exist. In the U.K. one can incorporate a limited liability company, ready to perform whatever activity also on the international market in just three working days. To further reduce the technical time required, readymade companies are available, incorporated six months to two years in advance. That is, a market of empty shells.

One wonders which kind of urgency would justify the need to avail oneself of a ready-made company in one day. Perhaps, to take part in an expiring competitive tender? Or to put a sum of hot money safely away? As for the details, one learns that keeping company accounts is not compulsory when the turnover is less than GBP 350,000. At the end of the fiscal year one has just to file a copy of the Annual Returns to the Register of Companies in Cardiff. The VAT number is not compulsory for turnovers less than GBP 55,000. The Corporation/ Company Tax Return is to be filed only by those 
with a regular activity. Dormant accounts have only to file an informal return to the Inland Revenue every year. These are regulations clearly written for dummy companies.

Another noteworthy jurisdiction as for company regulation is Delaware. A member state of the American Union, it hosts $40 \%$ of the companies listed in the New York Stock Exchange. The shares are registered, but the partners indicated at the incorporation are not reported in any list or registry. So they are, de facto, anonymous.

"One gets the maximum operative advantages for the Limited Liability Companies (LLC) in the case of a single shareholder, with residence outside the U.S., a circumstance exempting from tax withholding. No taxation is due for activities performed outside the U.S., nor is an annual account compulsory.»

"It is possible to increase the level of anonymity by asking for a nominee director and trustworthy shareholders who act in the place of the beneficial owner.

These names are recorded in the Company Registration Office, in Delaware and are public. All of this does not restrain the faculty of the beneficiary/owner to maintain the control of the company and to make bank movements. Besides, official (not public) documents are drafted to guarantee the beneficiaries the control of their company. The trustees have no executive power and no signature on the company's bank accounts"[3].

Similar conditions are offered in plenty of other places. In the British Virgin Islands (an archipelago of forty Caribbean islands), International Business Companies do not have "the burden to keep official or tax registers. At will, they may be opened anywhere in the world, a methodology that guarantees perfect anonymity to the partners. There are no taxes, either on capital or profits, dividends, interests, copyrights, clearings, successions. Finally, the annual accounts are not registered nor recorded by government offices" [3]. As we can see, the conditions are quite similar to those in the U.S. and the U.K., yet only the Caribbean islands are popularly reputed as a tax haven. The big Anglo-Saxon countries, on the contrary, appear among those respecting international regulations.

If all the world is offshore towards any single country and any company can operate abroad, being somehow "insulated" from the local regulations, whatever differences between onshore and offshore don't make sense any longer. Actually, in the case of a company incorporated abroad, the country of residence of the possible owner becomes for its part "abroad".
This is the architecture of multinationals, which this way combine the advantages obtained from the different locations. The nature of these advantages allows us to distinguish meaningful categories of countries (or jurisdictions) according to their prevailing economic function. In this respect, the mentioning of "favourable regulations to the establishment of financial services,» as in the case of London, is of particular interest. Not surprisingly, in each European country the biggest company using offshore subsidiaries is a bank.

An offshore bank is a credit institution located outside the country of its depositors. As all the banks may deal with foreign capitals, each of them belongs to this category, at least for part of its activity, without the need to resort to subsidiaries. When this is the case, it is to avail themselves of the special advantages mentioned before. The typical location of the banks generally considered as offshore is not casually in a jurisdiction characterized by low or no taxation, also granting legal advantages (secrecy) and protection against political instability. They must have an easy access to the deposits, and this is why such institutions were originally established in the Channel Islands, about halfway between London and Paris and in Switzerland, a country bordering Austria, Germany, France and Italy. Obviously the evolution of modern electronic communications has overcome the importance of geographical constraints. Wherever we register an anomalous concentration of banking institutions, e.g. a financial structure oversized for the needs of the local economy, we are witnessing an offshore financial centre [4].

\section{The tax havens}

The management of capitals in this environment requires a set of uncommon competencies. Not casually, in the last 15 years a plenty of manuals have been published all over the world [5] [6]. Also the academics [7] [8] paid attention to the theme. These essays are full of details about the most opaque face of globalization, e. g. the international transfers of capital, but given the subject there is often a scarcity of statistical data [9]. Needless to say that private capitals illegally transferred abroad are of paramount dimension: 2010 estimates range from 21 to 32.000 billion $\$$ [10]. So there is room also for a book as fascinating as not academically structured, written by an economic journalist sponsored by Tax Justice Network $^{1}$ [11]. Referring to the mechanism of

${ }^{1} \mathrm{TJN}$ is a coalition of researchers and activists fighting tax avoidance in the world. An independent international body 
transfer pricing, the author notes that every set of commercial exchanges gives origin to "value chain" following a double route, one for the real goods and another for the related records. The latter circuit represents the very heart of globalization, which is based on the concept of offshore.

For a country traditionally facing the sea like Britain, the term offshore means far from national regulations. In essence, "outlawed". In this dimension, fundamentally without limits, there is space for a variety of jurisdictions, in which the national jurisdiction tends not to interfere. This allows the birth of the so called tax havens, a word that appears somehow reductive.

The concept is inevitably subjective [7, p.45] Shaxson proposes a wide definition, that of "a place seeking to attract companies by offering politically stable structures to help individuals and legal entities to bypass the norms, laws and regulations of other jurisdictions" [11, p.15-16]. In this light, one understands why since the end of the 1990's in the U.S. they have begun to speak of "secrecy jurisdictions.» Secrecy integrates and reinforces legal separateness, both outward and inward. These jurisdictions preserve systematically a clear separation between the respective economies and the offered services, in order to protect themselves from their own offshore tricks.

Rebus sic stantibus, it is difficult to consider them as a sort of non-places, or better, realities very far from the rest of the world. It appears evident when we look at the various lists prepared by international bodies (OECD, IMF, etc.), where it is common to find countries seemingly "normal" such as Great Britain, New Zealand, the U.S.A. The geographer finds himself in trouble when trying to frame the phenomenon. Shaxson is suggesting that the geographical character may be somehow misleading, pointing out that we ought to look at the offshore as a process instead of as an object. So we are not facing a set of geographical entities, though exceptional, but an activity that is being carried out through a net of relationships. These are not necessarily characterized by their spatial attributes, yet they rely on specific structures that have by necessity a geographical base. Here we may appreciate the ambiguity of globalization, which is affirming itself through the eclipse of nation states. This addresses modern geographical thought towards an investigation of networks and flows, aimed at identifying new, meaningful partitions of the world, no more linked to the classic logic of Ratzelian origin.

launched in 2003, it is a U.K. company controlled by a not profit organization registered in Belgium (www.taxjustice.net).
To the geographer, the first and simplest operation consists in collecting the existing documentation and locating on the map the different "noteworthy places" of this "outlawed archipelago.» The lists circulating at the international level help us in this task, but at first sight the results appear to be very poor. There is not, as is documented by an accurate economic analysis, meaningful role for the geographical distance between the offshore financial centres and the development of the financial markets [12]. It is, therefore, necessary to divide the set following the intrinsic characteristics of each element.

A step in this direction was made by international organisations. In the 2009 OECD list (see §4) the 82 jurisdictions considered have been divided into three subsets: white, grey and black countries. The criteria used were the attained level in the disclosure of information to other states compared to the international agreed standards. The white list reports the jurisdictions (40) that have substantially implemented these standards; the second, those committed, but that have not yet substantially implemented them (30 tax havens and 8 "other financial centres"); the third, the jurisdictions that have assumed no commitment (4).

The OECD classification divides the set into three categories, but it does not allow us to go any further.

In fact, any categorization is functional to a precise purpose and in this case, it seems to be the measure of the advancement progress towards the "new international order," that is to say the degree of integration into the global economic system. This suggests that the real purpose is not linked to the monitoring of tax havens. Such jurisdictions seems to be off limits, if only since they are not (in general) members of the organization. On a total of 42 , only 5 (the Netherlands, Austria, Belgium Luxembourg and Switzerland) meet this requirement. This criterion would distinguish the world of the good from that of the bad countries, which, not casually, result to be small and poor.

At this point, it appears of more interest to list the jurisdictions on the basis of the type of companies/corporations that they may host, prepared by a specialized operator [13]. The categorization, functional to the mentioned activity, distinguishes among Key International Business Company Jurisdictions (10, none of which appears in the OECD white list, while one of them - Dominica - is totally ignored), Popular Jurisdictions for International Trade, Investment and Tax Planning (19, 8 of which reported in the white list, 3 - Cyprus, Luxembourg and Rumania 
- not mentioned), and Countries with other Types of Companies (20, 12 mentioned in the white list).

A total of 49 jurisdictions, 20 of which formally meeting the OECD requirements. A further surprise, the U.S., which maintains to be the highest guardian of international law, is quoted in the website with specific reference to 7 federal jurisdictions. It is not a secret, in the Tax Justice Network international ranking 2009, the U.S. is classified at the top level in the world as for secrecy, with an opacity score of $92 / 100$, the same level of the Cayman Islands, the British Virgin Islands and the U.S. Virgin Islands too. However, the reality is even worse, as we shall see.

To sum up, the company is openly conveying to the public ranking of the offshore, based on the turnover and the distance from the morality in business. A picture casting heavy shadows on the comfortable view transmitted by the OECD. Particularly shocking is the scarce or no distinction between "respectable" and "non-respectable" countries. A common practice among specialized companies. "We have experts to advise you on the selection of the best offshore company formation, or onshore company jurisdiction for your offshore or international business" [14]. In the TJN 2011 list the U.S. get down to the fifth position and the U.S. Virgin Islands disappear [15], but the picture does not change. Leaving aside the official categorizations (OECD, FATF), all prepared following criteria of political opportunity, the mingling of "normal" countries and "ill-famed" territories appears steady.

As we have seen before, only look at the underlying key elements allows to understand the reality. More than a physical space, made by a set of places, the offshore system is a set of activities performed in relatively few centres, but out of opportunism they take a legal form on separated premises. Exploiting the laddering technique, certain financial structures are functional among different jurisdictions, "each of them attributing new legal or accountancy "shells" to the capitals, which are usually located elsewhere” [11, p.34]. In essence, there are a number of conveyances and here comes the geographical factor again.

First of all, we ought to recognize that capitals, the real object of the transactions, do not move, they simply change their denomination and legal shape. Only documents are transferred, and, therefore, from the point of view of revenue authorities, that is shared by geography - a discipline deeply rooted in the factual world - these are purely fictional transfers. The assertion that “offshore activities don't occur in any jurisdiction, but take place in the interstices between the jurisdictions" [11, p.35] sounds as a geographical metaphor, thus being intrinsically misleading. The discontinuity is not based on geography but rather on the kind of jurisdiction: that is to say, its nature is juridical. As scholars we are facing a quite new phenomenon, the financial space relying on sets of coordinates that are not purely Cartesian.

Coming to the point, we ascertain the existence of a network, as wide and articulated as dynamic, inside which transactions are carried out. A net offering a plurality of nodes, all of which capable of taking in turn the role of starting or receiving point. This explains the simultaneous presence on the market of highly qualified financial centres and of so-called "banana republics.»

\section{The geographical dimension}

Although fundamentally the system does not consist in geographical units but in a set of relationships, as a whole, it is possible to single out some organizational structures. Basically, three coherent subsystems are discernible, that substantially mirror the present geopolitical and geo-economic structure of the globe. We will examine each of them in order of importance.

As we may read in Fig. 1, the U.K. - or better the City of London - is the core of a set of offshore jurisdictions covering the whole planet. Functionally, it may be interpreted as a transformation of the former H.M.'s empire [7, p. 124129] to meet the needs of the postindustrial era. An analysis of the juridical status of each component reveals a stratification of geopolitical structures repeating the historical evolution of British power [16].

The starting point is a set, rather close up, made of institutions clearly of medieval nature: the City of London, the Channel Islands, the Isle of Man. These latter are defined as "Crown Dependencies," while the City, that represents the core of the entire system, is holding the status once characterising the city states integrated into the spatial organization of empires. It benefits of substantial autonomies as regards not only the London City Council but also the British government and the Crown itself.

Outside the British Isles, there is a network of typical colonial character, the "Overseas Territories,» representing the remains of the empire. To tell the truth, at the moment only half of these island states appear in the lists of tax havens. All around these small spots scattered on the oceans we meet a much wider postcolonial network, made of fully independent states. Most of them are members of the Commonwealth of 


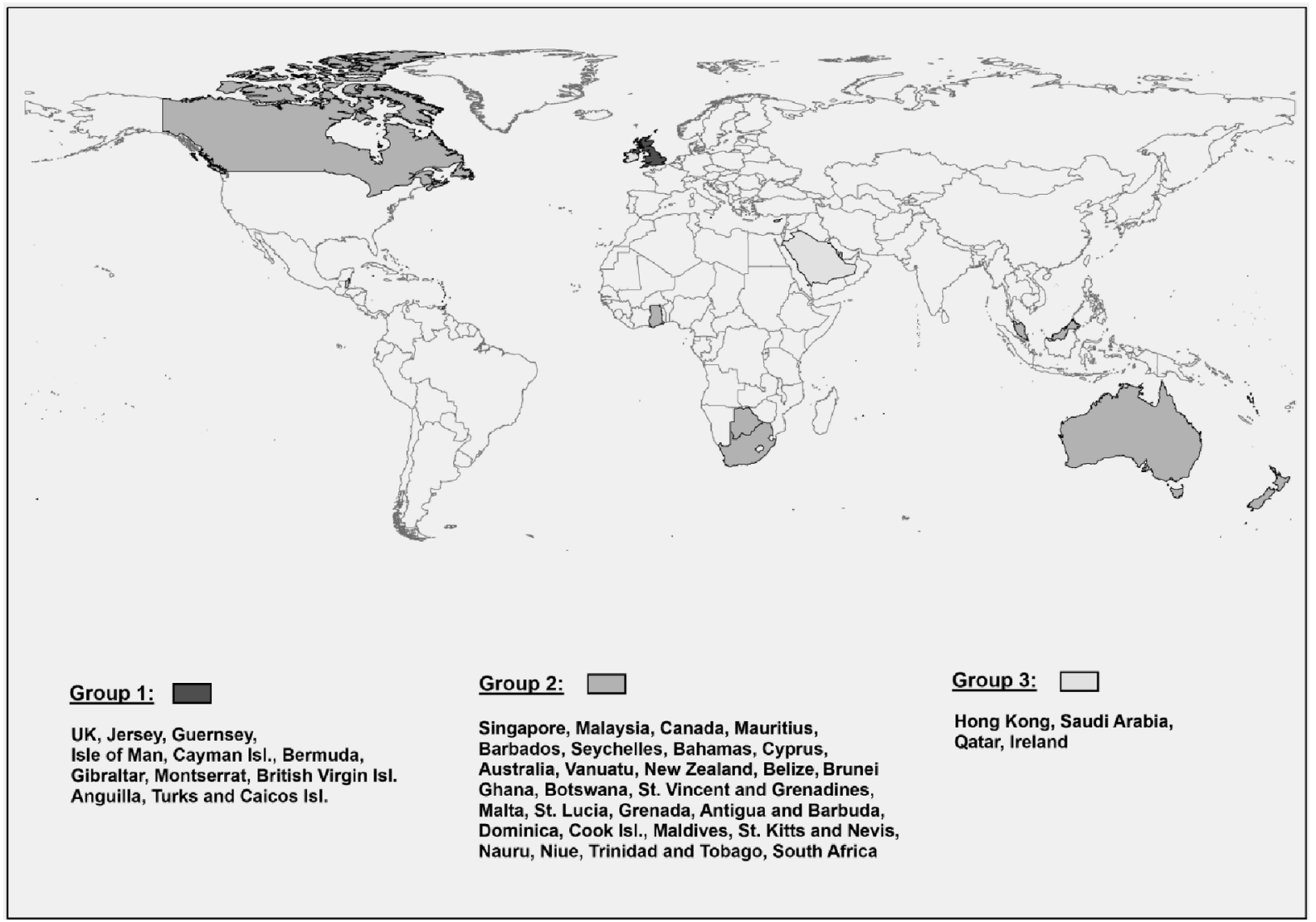

Source: Author's elaboration with data from OECD (2009-2012) and TJN $(2011,2013)$

Fig. 1. The Commonwealth Offshore Network

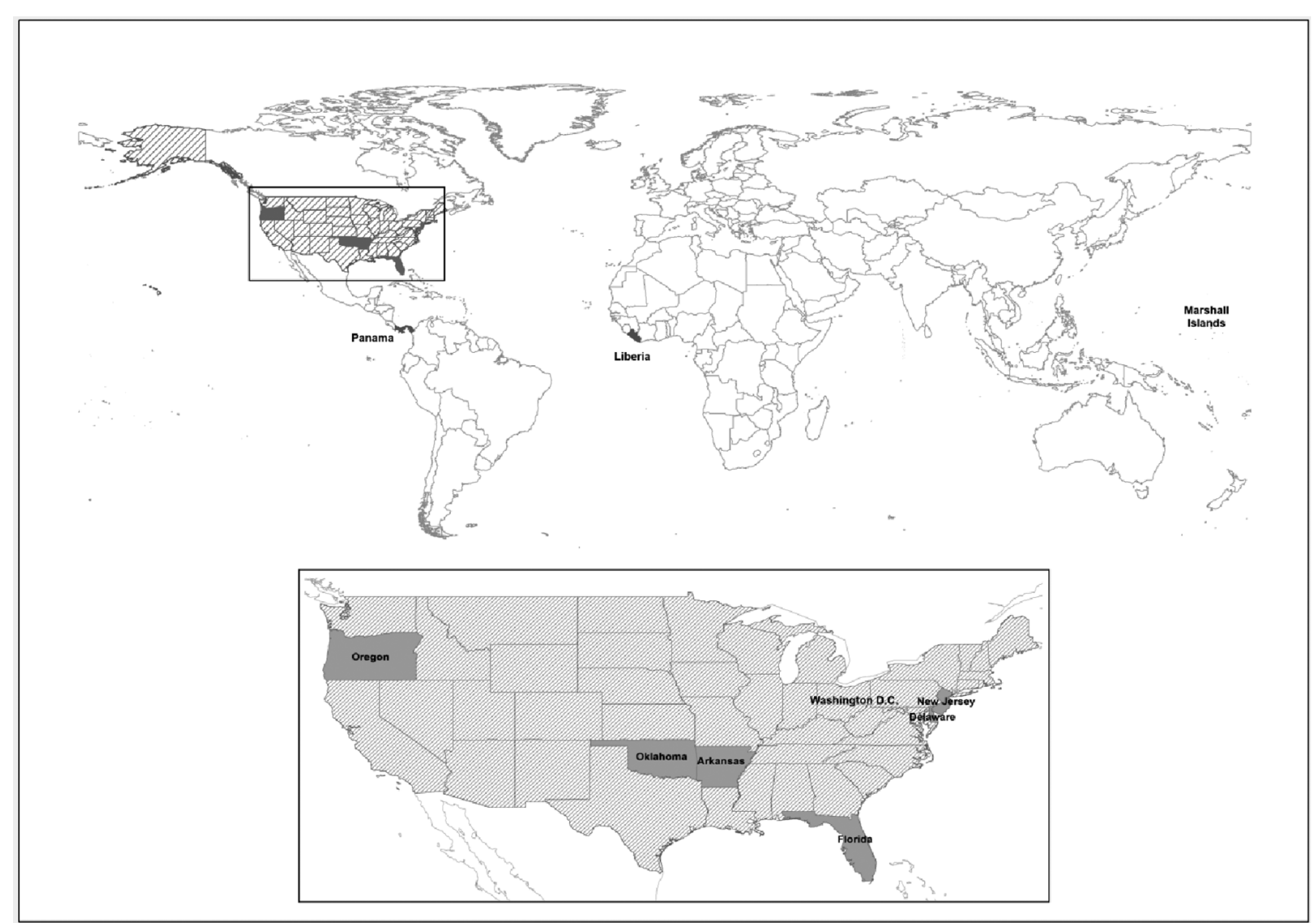

Source: Author's elaboration with data from OECD (2009-2012) and TJN $(2011,2013)$

Fig. 2. The U.S. Offshore Network 


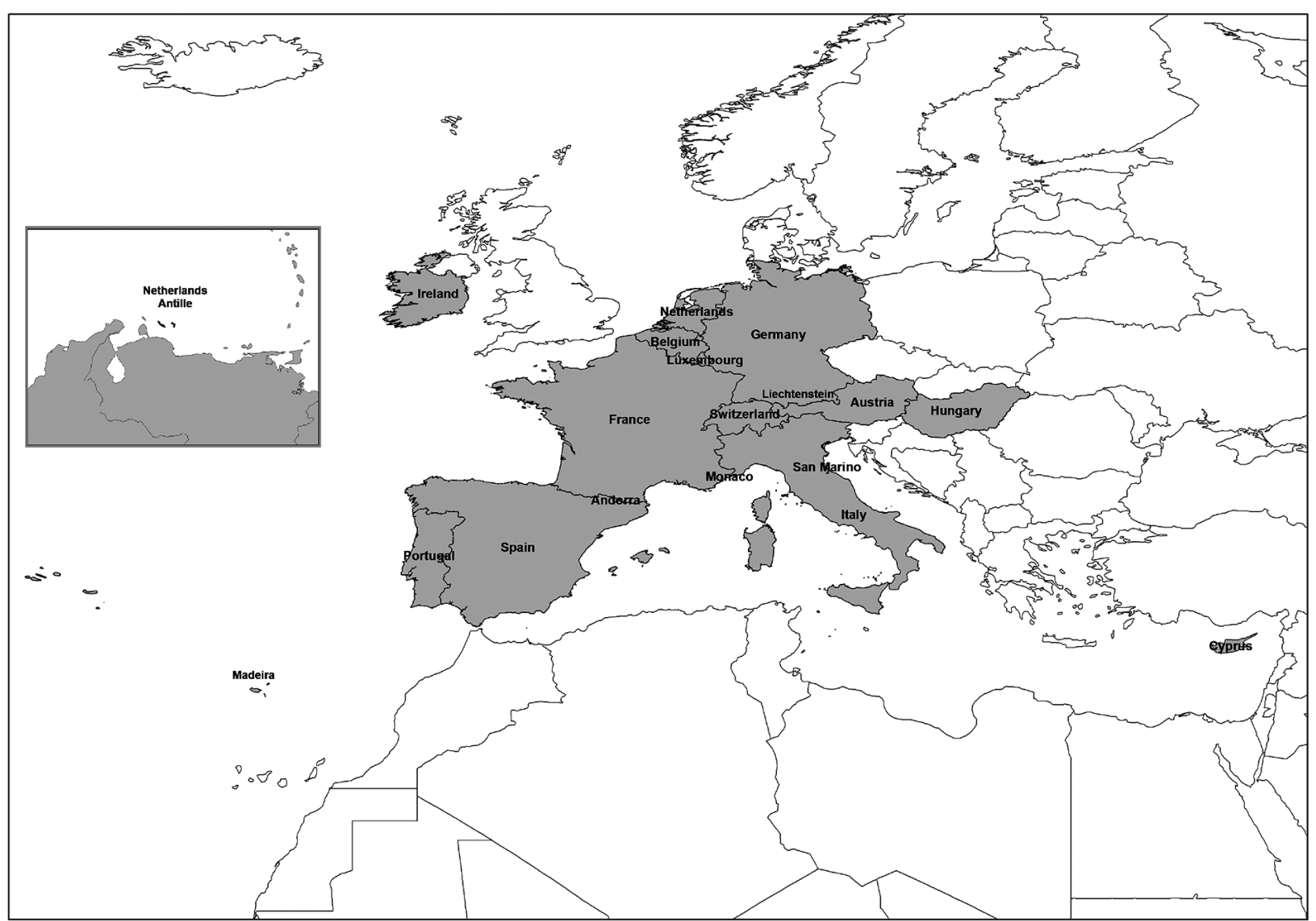

Source: Author's elaboration with data from $\operatorname{OECD}(2009-2012)$ and TJN $(2011,2013)$

Fig. 3. The European Offshore Network

Nations, and this is the reason for the denomination of the map. The nature and level of linkages kept up with the U.K. is variable according to the economic dimension and the political situation at the moment.

All together, this network is credited for more than $50 \%$ of all bank assets in the world (with about $12 \%$ booked in the City itself, which competes with New York for the role of most important financial centre on the planet). The whole system is, however, much wider and in uninterrupted evolution.

As the main financial power in the world, the U.S. succeeded in creating their own zone of influence articulated, even better, in three levels (Fig. 2). The first one is represented by the Union as a whole. Federal tax breaks and regulations favouring secrecy, analogous to those offered in classical tax havens, have been enforced since 1921 to attract foreign capitals from whatever origin. The second one, as we have seen before, is to be found at the level of member states, who offer even more attractive conditions. Delaware, for instance, was qualified in the most opaque jurisdictions, in the world [15], but Wyoming and Nevada both allow to issue bearer shares. Also New Jersey, Florida, Arkansas, Oklahoma and Oregon are ac- tive in intercepting travelling capitals, as well as Washington, DC. ${ }^{1}$ Third, a little net of (formally) independent countries: Panama, Marshall Islands, Liberia. Of course, the systemic core is located in the international financial centre of New York.

Traditionally, the offshore system of continental Europe is based upon banks located in countries like Switzerland, Luxembourg, the Netherlands, Liechtenstein, Monaco (and occasionally Andorra and Madeira) (Fig. 3). In reality, specialized firms offer to open and manage companies in twenty-seven European jurisdictions, openly defined as offshore [14]. It is a set of interrelated units, which however lacks a unitary organization, thus reflecting the political fragmentation that is still a characteristic of the continent. No wonder that both the continental nations (which are trying to create a viable Euro-zone) and their offshore network are losing importance in the global arena.

All the networks are highly interconnected both in their single nodes and at the systemic level. It follows that each jurisdiction can shift from a network to another, change its role and its hierarchical degree, and also take part in differ-

\footnotetext{
${ }^{1}$ All of these jurisdictions are in some way advertised by specialized companies (see: Ocra, 2013).
} 


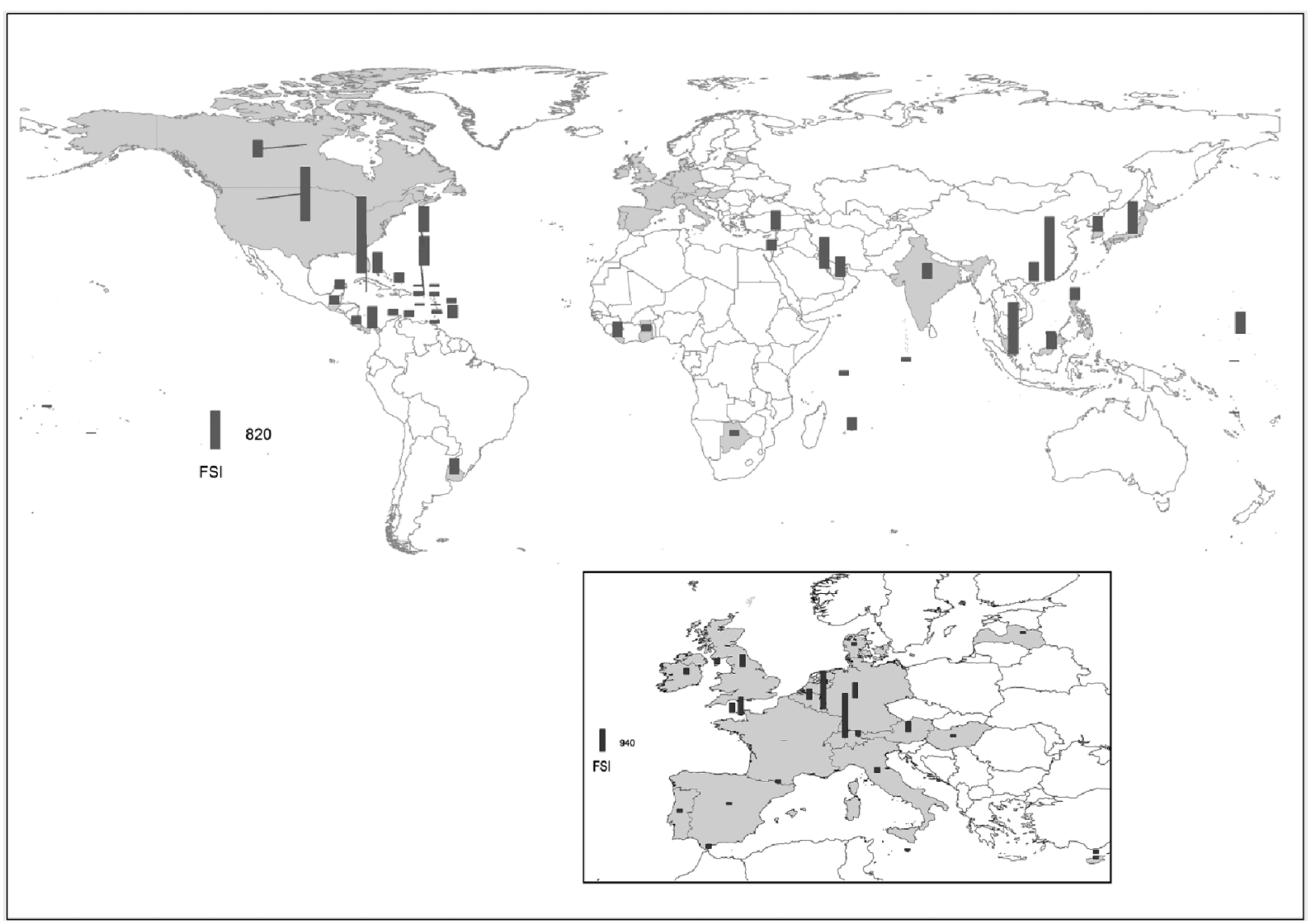

Source: Author's elaboration with data from TJN, 2011

Fig. 4. World Financial Secrecy Index (FSI), 2011

ent subsystems at the same time. Year by year new jurisdictions are joining the global network and new subsystems are emerging. The most noteworthy of them is the Chinese one, articulated in a variety of jurisdictions - special economic zones, free-trade zones (like that of Shanghai), the special administrative zones of Hong-Kong and Macau - moreover foreign financial centres like Singapore.

TJN recognizes 69 harmful jurisdictions in 2005, 60 in 2009, 72 in 2011, and 82 in 2013. The criteria followed by this centre are rather extensive, e.g. it considers as an index of opacity the unavailability of online data concerning single companies, a requisite that no jurisdiction in the world is currently satisfying. The underline logic is to focus the nodes in the offshore network, and in so doing the results appear undoubtedly of interest. Through combining the opacity score and the volume of financial transactions, they calculate a financial secrecy index (FSI) that we have mapped in Fig. 4 [15].

The kind of information conveyed by this index does not correspond, strictu sensu, to its denomination. In fact, it is ranking the position of each ill-famed financial jurisdiction, that is to say its degree of global harmfulness.

\section{The politics to the offensive}

In the 1980s and 1990s, because of the staggering growth of international transactions, the activity of tax havens, once simple trouble-makers in the market, progressively became a threat to the budget of many both industrialized and developing countries. In 1997, as a consequence, a group of 87 nations requested the OECD to launch a "harmful competition initiative.» This led in 1998 to the publication of a report on the issue, followed by three others in the years 2000, 2001 and 2004. The first report established the criteria for identifying a tax haven. A "black list" of 35 harmful jurisdictions was disclosed in 2000 while other jurisdictions, identified as "potentially harmful,» was made public only in 2004.

In the same year 2000, an analogue initiative was undertaken by the Financial Action Task Force (FATF), an intergovernmental body founded on the initiative of G7 in 1989 and charged with fighting money laundering and the financing of terrorism [17]. Under this respect, 15 jurisdictions were singled out, and further eight in the following year. Another target was introduced in a 2001 report by the Financial Stability Forum [18], focusing on the offshore financial centres (OFCs). These clusters of financial institutions are running part of their 
business through tax havens, no matter if they do not share the same geographical location. The distinction is fundamental to understand the architecture of the offshore system.

The release of lists of countries and territories, especially from the OECD, was not followed by punitive measures. It was a pure exercise of moral suasion that proved to be effective: all the mentioned jurisdictions were eager to be deleted from something perceived as an infamous category. To this purpose it was sufficient to sign an advanced commitment letter, promising to put an end to harmful practices not later than December, 2005. This led to a speedy deflating of the lists. The OECD one dropped to 7 "non cooperative" jurisdictions in 2002, three in 2005 and was completely empty at the date of April 4, 2009. The one prepared by FATF reduced to one in 2006 and zero in 2007.

Notwithstanding different opinions [19], nothing changed in practice and we had to wait until August 2007 to see the entire reality come to the light all of a sudden. Around the offshore system had been developing something much more serious than a "cops and robbers" game between national revenues and international capitalists. In the accommodating environment of tax havens a sizeable part of the parallel financial system now called shadow banking [20] had been taking roots. This non-regulated sector, whose dimension was to surpass that of all U.S. banks, is responsible for the packaging and selling on the markets of a bulk of toxic assets that finally provoked the implosion of the global financial system.

This abrupt awakening led to a radical change of attitude in the national authorities and, of consequence, in the international organizations. To guarantee the national budgetary base remained a must for all governments, now engaged in an agonizing effort to save their banks, but another need that could not be deferred became to build up a global financial intelligence machine to avoid another crisis in the dark. During the G20 meeting in London (April 2, 2009), aimed at a Global Plan for Recovery and Reform, an agreement was reached concerning the new type of country classification we have mentioned before [21]. It was linked to a four-tier categorization, based on the degree of compliance with internationally recognized standards.

The new white list was to host the jurisdictions committed to these standards, the black one those not committed, while a grey list was reserved to those entities who had not yet implemented their engagements. The grey list was moreover divided into tax havens (G1) and "other financial centres"
(G2), somehow suggesting that they were just one grade less harmful than the "black jurisdictions." As regards, the scheme adopted in 2000, in the new categorization the hierarchy of criteria was overturned. Taxation levels and preferential fiscal regimes became of secondary importance as regards the overall degree of opacity characterizing each jurisdiction towards the outside world. Opacity was unanimously considered as the main condition allowing the arrangement of new speculative operations potentially destructive at a global level.

Owing to the seriousness of the economic situation, the harmful jurisdictions were now explicitly threatened with discriminatory fees, denial of market access, and other forms of financial retaliation. Notwithstanding the diffuse international consensus, lively reactions were not absent. Meaningful were the statements from the Commonwealth Secretary-General and the Republican majority leader in the House of Representatives of the U.S.

Both were deeply concerned with the consequences that an impartial governance of world financial transactions would bring to the interests they sponsored. Excited accents were registered also in Europe, coming from countries like Austria, Luxembourg and Switzerland, who declared to be victims of a defamatory campaign.

To begin with, all jurisdictions were required to sign at least 12 international agreements concerning the exchange of information, along the lines of those preventing double taxation. This in turn induced almost all of them to a frenzied diplomatic activity. The result was a new clearance of black and grey lists. From April to September the G1s reduced from 30 to 26 , the $28 \mathrm{G} 2 \mathrm{~s}$ dropped to 10 , while all the black ones disappeared. In October, 2010 the 80 jurisdictions were all considered regular. Clearly it was another outward operation, that produced no effect as to the illicit piling up of capitals [22].

Hence the need of a serious assessment, requiring periodic monitoring of the entire system, finalized at promoting the effective implementation of OECD standard within the 2012. This action was positively started that year through a peer review articulated in two phases. The former consisted in a review of jurisdiction laws, concerning both internal than international transactions. The second one regarded a check out of the effective implementation of those laws.

The outcome was made public in the 2013 Report to the G20 leaders [23]. Now there are no lists of good and naughty, but tables reporting the position of each country as regards the number of 
elements. So it is not easy to draft a classification. On the whole, 46 jurisdictions out of the 98 analysed are more or less not regular, 14 of them having not yet entered phase 2 . All of them have in common a bureaucratic organization at an embryonic state and generally bad reputation, which leads to suspect the possibility of passive resistance. As for the others, 4 are rated as "non compliant” (Cyprus, Luxembourg, The Seychelles, British Virgin Islands), 2 "partially compliant" (Austria, Turkey), and 26 "largely compliant."

In December, 2012 the European Commission (the EU's executive body) had declared war on tax avoidance and evasion, which it said cost the Union a trillion euro a year. In April 2013, five EU countries (Germany, France, Italy, Spain, U.K.) had announced a "multilateral pilot agreement" on the exchange of information to fight tax evasion. For his part, the French premier F. Hollande told reporters his intent to eradicate tax havens in Europe and in the world. ${ }^{1}$

In June there had been a memorandum in 10 points, issued by the G8 group of industrialized countries, aimed at the recovery of the world economy, a goal to be partially obtained through a further dismantling of state protectionism, a reduction of border bureaucracy and an improvement of transparency in fiscal matters. It was hoped for a change in national regulations allowing companies to shift their profits abroad. Multinationals were to adopt the "country-to-country" reporting, so as to nullify the advantages of a group sharing agreements. Automatic sharing of detailed fiscal information would create a unique fiscal space worldwide.

At the end of the month, the National French Tax Evasion Action Plan was disclosed. It was a list of goals to be transformed into operative regulations to enhance tax transparency and prevent misuse of companies and other vehicles, including trusts, as part of the commitment to the G8 group.

\section{Conclusions}

The escalation of statements is impressive, but which real progress can be registered in this war against fiscal crime? Notwithstanding the obvious

\footnotetext{
${ }^{1}$ France is supposed to be a victim, rather than a protagonist, of tax evasion. The country was never on the OECD blacklists, and has been definitively included in the TJN Report only in 2013 (in the 43rd position). As for the connected jurisdictions, Monaco and Samoa now appear in the last positions (75th and 76th respectively) and the problems with nearby Switzerland are well known. To tell the truth, several France jurisdictions appear in the list of tax havens produced by the Italian Ministry of Finance in 1999 and 2001. These are Djibouti, New Caledonia, French Polynesia and Samoa.
}

resistance of the business world, mainly with a low profile, there is some. In November, 2012 Australia was the first non-European country to change the regulations permitting multinationals to shift their profits abroad. New rules oblige all banks operating in the U.S. to transmit the annual accounts and documents concerning the assets held abroad by American citizens. Inside the European Union all countries known for their role in the field have been subjected to a growing pressure to modify their own regulations. Formally, they capitulated one by one, but the implementation of the agreed inter-European tax standard - that is a new code of fiscal communication among the countries is far from being a reality. There is still a strong internal resistance both in Switzerland ${ }^{2}$ and in Austria. In the latter case, bank secrecy is embodied in the Constitution.

The most dramatic event has been, however, the Cyprus crisis, which in March 2013 wiped out one of the most important tax havens in Europe, especially in the Mediterranean. To note, it was also the biggest pipeline for the capitals flowing away from the former Soviet Union. The event was jointly orchestrated by financial authorities in the EU and the IMF, motivated by the bankruptcy of credit institutions in the island, which recalled the cases of Iceland and Ireland. Anyway, the result was a brutal ending of a tax haven, never experienced before. However the real news, in a world where secrecy is a basic rule, is the so-called "operation Offshore leaks.» It is an offensive on a global scale, accurately planned in the U.S. inside a non-profit organization in Washington, the Center for Public Integrity.

Through an organisation named International Consortium of Investigative Journalists [24], since November 2012 a mass of some 2.5 million documents concerning the registration data of 122,000 offshore companies in 170 jurisdictions were circulated in the press. Most of the documents concerned the British Virgin Islands, till then one of the most reliable and popular jurisdictions.

As a consequence, the government of the Cayman Islands announced in January 2013 that it would prepare a public database of the companies locally incorporated. Not a big effort, for the jurisdiction that hosts some 9,438 hedge funds and had played a first class role in the securitisation of American assets.

Whatever the aims of the press campaign orchestrated on a world scale [25], noteworthy with

\footnotetext{
${ }^{2}$ Remember that Swiss banks have released to the U.S. Inland Revenue a list of some 4,000 American citizens holding assets in the Confederation.
} 
the active part of British media, in the near future the offshore system might undergo radical changes in order to survive the effects of the economic crisis under way.

What seems to be sure is the end of the old fashioned European system of cyphered accounts that almost everyone could open in a complaisant jurisdiction, in favour of the Anglo-Saxon system, supported by a network of trustees. It also means the extinction of the European network, and with it a loss of capacity to accumulate capitals abroad for those countries. Of all this will benefit the U.S. and the U.K., that have urgent need to rake up financial activities from all over the world, to counteract the inflationary effect of the massive emissions of liquidity by their central banks, and to finance the re-industrialisation of their economies. The latter is a goal U.S. had already privileged in the 1930s, thus triggering the collapse of the German economy.

\section{References}

1. http://www.gprime.com/index.php?main_file=CNGf4ori_servizi\&cated=1 (consulted on June 13, 2013).

2. Ocra worldwide (2013). Retrieved from http://www.ocra.com/downloads/jurisdiction.asp (consulted on June 12, 2013).

3. Ocra worldwide (2013). Retrieved from http://www.ocra.com/services/offshore_banking02.asp (consulted on June 26, 2013).

4. Zoromé, A. (2007). Concept of offshore financial centers. In search of an operational definition: IMF, WP/07/87. Retrieved from http://www.imf.org/external/pubs/ft/wp/2007/wp0787.pdf.

5. Tasca, G. Vietti, M. (2009). Società offshore e paradisi legali. Regole e disciplina, Milano: Giuffrè.

6. Degregori, I. (2013). Paradisi fiscali e società offshore, Edizioni R.E.I.

7. Palan, R. Murphy, R. and Chavagneux, C. (2010). Tax Havens: How Globalization Really Works, Ithaca: Cornell University Press.

8. Zucman, G. (2013). La richesse cachèe des nations. Enquete sur les paradis fiscaux, Paris: Seuil.

9. Wojcik, D. Boote, Ch. (2011). Tax havens: how globalization really works, Ronen Palan, Richard Murphy and Christian Chavagneux. Journal of Economic Geography, 11:753-756. doi: 10.1093/jeg/lbr008.

10. Henry, J. S. (2012). The price of offshore revisited. Retrieved from http://www.taxjustice.net.cms/upload.pdf/ (consulted on January 22, 2014).

11. Shaxson, N. (2011). Treasure Islands: Tax Havens and the Men Who Stole the World, London: The Bowley Head (Italian edition,2012). Le isole del tesoro. Viaggio nei paradisi fiscali dove è nascosto il tesoro della globalizzazione, Milano: Feltrinelli).

12. Rose, A. K. and Spiegel, M. M. (2007). Offshore financial centres: parasites or symbionts? The Economic Journal, 117: 13101335. doi: 10.1111/j.1468-0297.2007.02084.x.

13. http://ocra.com/services/offshore_companies.asp?gclid=CNGf4ori (consulted on June 12, 2013).

14. Dema Partners Ltd. Retrieved from http://worldwideoffshore.com/fees/jurisdictions-2? gclid=CMik60kgrgCFYT (consulted on June 26, 2013).

15. Tax Justice Network, Financial Secrecy Index. Retrieved from http://www.financialsecrecyindex.com/ (consulted on June 13, 2013). Tax Justice Network (TJN). Retrieved from http://taxjustice.net (consulted on June 10, 2013).

16. Biagini, E. (2006). Rule Britannia: The Wielding of Global Power, Halle: Projekte-Verlag.

17. Financial Action Task Force on Money Laundering. Retrieved from http://www.fatf-gafi.org (consulted on June 13, 2013).

18. Offshore Financial Centers (OFCs): Note for the IMF Executive Board, June 29, 2001. Retrieved from http://imf.org/external/ $\mathrm{np} / \mathrm{mae} /$ oshore/2001/eng./062901.htm (consulted on January 13, 2014).

19. Avi-Yonach, R. S. (2009). The OECD Harmful Tax Competition Report: A Tenth Anniversary Retrospective. University of Michigan School of Law. John M. Olin Center for Law \& Economics, W.P. No 08-013. Retrieved from http://www.law.umich.edu. centersandprograms/olin/papers.htm

20. Pozsar, Z. Adrian,T. Ashcraft, A. Boesky, H. (2012). Shadow Banking: Federal Reserve Bank of New York, Staff Report N. 458. Retrieved from http://www.newyorkfed.org/research/staff_reports/sr458.pdf

21. Oecd and the London G20 Summit in 2009. Retrieved from http://www.oecd.org/economy/oecdandthelondonsummitin2009.htm (consulted on November 20, 2013).

22. Johannessen, J. N. and Zucman, G. (2012). The End of Bank Secrecy? An Evaluation of the G20 Crackdown. Retrieved from http://bi.edu/InstitutterFiles/SamfunnsC3\%B8konomi/Papers/Spring\%202012/Johannesen.pdf (consulted on June 5, 2013).

23. Global Forum Transparency and Exchange of Information for Tax Purpose, Jakarta, November 21-22, 2013. Retrieved from http://www.oecd.org/tax/transparencyENG \%20Jakarta\%Statement\%20of\%20Outcomes.pdf (consulted on January 5, 2014).

24. The International Consortium of Investigative Journalists. Retrieved from http://www.icij.org/ (consulted on June 28, 2013).

25. Katasonov, V. (2013). Tax free offshore banking havens: hidden agenda behind operation "Offshore Leaks"? Centre for Research on Globalization. Retrieved from http://www.globalresearch.ca/globalization.org.

\section{Information about the author}

Battisti Gianfranco (Trieste, Italy) - Doctor of Economics, Professor of Geography, Department of Humanistic Studies, University of Trieste; Coordinator of the Working Group on the Geography of Energy of the Association of Italian Geographers (DISU, via Tigor 22, 34122 Trieste, Italy, e-mail: gbattisti@units.it). 